\title{
Concurrent Repair of Orbital Shallowness with Craniosynostosis Surgery: Two Late Cases of Simultaneous Orbital Decompression
}

\author{
Kraniyosinostoz Cerrahisi ile Ayn Seansta Orbital Siğllk Onarmu: \\ Eş Zamanl Orbita Dekompresyonu Yapılan İki Geç Vaka
}

\author{
Ali Rıza OREROGLU ${ }^{1}$, Gokalp SILAV² ${ }^{2}$ Ozay OZKAYA ${ }^{1}$, Cagdas ORMAN ${ }^{1}$, Mithat AKAN ${ }^{1}$ \\ ${ }^{1}$ Istanbul Okmeydanı Research and Training Hospital, Plastic, Reconstructive and Esthetic Surgery Clinic, Istanbul, Turkey \\ ${ }^{2}$ Acibadem University, Acıbadem Maslak Hospital, Neurosurgery Clinic, Istanbul, Turkey
}

Corresponding Author: Ali Riza OREROGLU / E-mail: alireza@oreroglu.com

\begin{abstract}
Early closure of cranial sutures results in various types of cranial vault deformities, named craniosynostosis. Although mostly associated with syndromic cases, bony orbit deformities such as exorbitism can be seen with various types of craniosynostosis. This condition can be associated with papilledema and besides its effect on the patient's appearance can cause subluxation of the globe, lagophthalmos or keratitis resulting in corneal ulcers and ultimately loss of vision. Various techniques have been proposed for repair or exorbitism such as fronto-orbital advancement procedures, orbital wall decompression, periosteum scoring and tissue excision. Orbital periosteal scoring covering the globe can be extremely efficient for orbital fat decompression when combined with other orbital volume expanding procedures. We hereby present two late cases of craniosynostosis associated with bilateral exorbitism due to orbital shallowness for which cranial vault reconstruction was performed simultaneously with combinations of fronto-orbital advancement, orbital decompression and periosteal scoring. The late referral of these patients at ages older than the usual time of operation indication made the surgical procedure for craniosynostosis repair and exorbitism treatment challenging. The combined and simultaneous use of bone advancement, orbital wall decompression and specially periosteum scoring can be highly efficient in the treatment of exorbitism associated with craniosynostosis.
\end{abstract}

KEYWORDS: Craniosynostosis, Exorbitism, Brachycephaly, Frontal advancement, Periosteal scoring, Orbital decompression

ÖZ

Kranial sütürlerin erken dönemde kapanması kraniosinostoz olarak adlandırılan çeşitli kranial kubbe bozukluklarına neden olur. Kemik orbita deformiteleri çoğunlukla sendromik nedenli kraniosinostozlarla görünmesine rağmen kemik orbita deformitesi olan egzorbitizm çeşitli kraniosinostozlarla beraber görülebilir. Böyle durumlarda papilödem ve bunun sonucunda hastada görünüş bozukluğu yaratan glob subluksasyonu, lagoftalmus veya korneal ulserle sonuçlanan keratit ve en nihayetinde görme kaybı oluşabilir. Egzorbitizm tedavisi için çeşitli teknikler planlanmıştır. Günümüzde de bu amaçla fronto-orbital ilerletme prosedürleri, orbita duvar dekompresyonu, periostal skorlama ve doku eksizyonu uygulanmaktadır. Orbita periost skorlama, orbita hacim genişleten prosedürlerle birleştirildiği zaman orbita yağ dekompresyonu için oldukça verimlidir. Bu yazıda, orbita darlığına bağlı bilateral egzorbitizm ile ilişkili iki kraniosinostoz vakasını sunduk. Vakalarımızda kranial kubbe rekonstrüksiyonu için fronto-orbital ilerletme, orbital dekompresyon ve periostal skorlama uygulandı. Bu hastaların normal operasyon zamanından daha geç dönemde operasyon endikasyonu konulması kraniosinostoz düzeltilmesi ve egzorbitizm tedavisi ile ilgili ameliyat prosedürünün başarı şansını azaltmaktadır. Kemik ilerletme, orbital duvar dekompresyon ve özellikle periostal skorlama kulanımının birleştirilerek eşzamanlı uygulanması kraniosinostozla ilişkili egzorbitizm tedavisininde oldukça verimli olabilmektedir.

ANAHTAR SÖZCÜKLER: Kraniyosinostoz, Egzorbitizm, Brakisefali, Frontal ilerletme, Periost skorlaması, Orbita dekompresyonu

\section{INTRODUCTION}

Craniosynostosis is a cranial deformity seen due to early closure of cranial sutures. This early closure results in a change in the cranial growth vectors due to compensatory forces hence creating a cranial deformity. In most faciocraniosynostoses, usually the syndromic cases, the bony orbits are deformed due to hypoplasia resulting in the inability of the orbital cavity to accommodate the orbital content. This disharmony of reduced orbital volume holding in a normal amount of retrobulbar soft tissue content results in globe protrusion, termed exorbitism (5). This condition although seen majorly in syndromic cases of craniosynostosis can be seen in nonsyndromic types as well. Whatever the case is, exorbitism can be an indication for early or urgent surgery $(6,4)$. Severe exorbitism can cause subluxation of the globe, mechanical lagophthalmos, keratitis due to prolonged exposure, corneal ulcers and loss of the eye in extreme cases (9).

Exophthalmos is a protrusion of the eyeball due to an increase in orbital contents in a normal bony orbit as compared to exorbitism, which is a protrusion of the eyeball due to a 
decrease in capacity of the orbital container, with a normal orbital content volume (2).

\section{PATIENTS and METHODS}

We hereby present two cases of non-syndromic craniosynostosis associated with exorbitism who presented at our clinic at a late age. Our first case is an 8-year-old male patient who presented at our clinic with a brachycephalic deformity due to synostosis of bicoronal sutures (Figure 1). The physical examination revealed cranial vault dysmorphism, mild papilledema as a sign of elevated intracranial pressure and bilateral exorbitism due to shallowness of the orbits. The patient complained of loss of vision acuity. Skull radiographs showed typical diffuse copper beaten appearance. An operation was planned with the neurosurgery team and total calvarial reconstruction was performed increasing the skull anteroposterior distance and reducing the skull height.

The exorbitism treatment was planned simultaneously by advancement of the frontal bar. The lateral orbital rim was left intact however a bony window was opened behind to let decompression of the orbital content. The periosteum of the orbit was elevated as a whole with the orbital contents and the globe. Scoring was applied to the superoposterior periosteum of the orbital wall attached to the globe in a horizontal and vertical fashion resulting in orbital fat decompression and regression of the globe protrusion (Figures 2, 3).
Our second case is a 10-year-old male patient who presented at our clinic with the same complaints, a cranial vault deformity due to multiple suture synostoses and bilateral exorbitism (Figure 4). This patient was also operated and the cranial vault deformity repaired using frontal bone advancement procedure performed as well as advancement of the frontal bar and the lateral orbital rim as one piece for treatment of the bilateral exorbitism. Scoring was applied to the periosteum of the orbital wall in the same way and orbital fat decompression was achieved intra-operatively (Figure 5, 6). The patient did not however come for follow-up in the post-operative period and clinical regression of globe protrusion could not be assessed (Figure 7).

There were no complications seen in the postoperative period for both cases.

\section{DISCUSSION}

The anterior projection of the eye with respect to the orbital aperture is a key anthropometric relationship of the upper human face for both aesthetic and functional reasons (8). Severe cases of exorbitism or Graves' exophthalmus result in abnormally protruded eyes that have a profound effect on the subject's appearance. In severe exorbitism or in grossly proptotic eyes, the upper eyelid cannot cover the globe anymore, leading to lagophthalmos, exposure keratitis, and corneal ulcers (9). In extreme cases, active contraction of

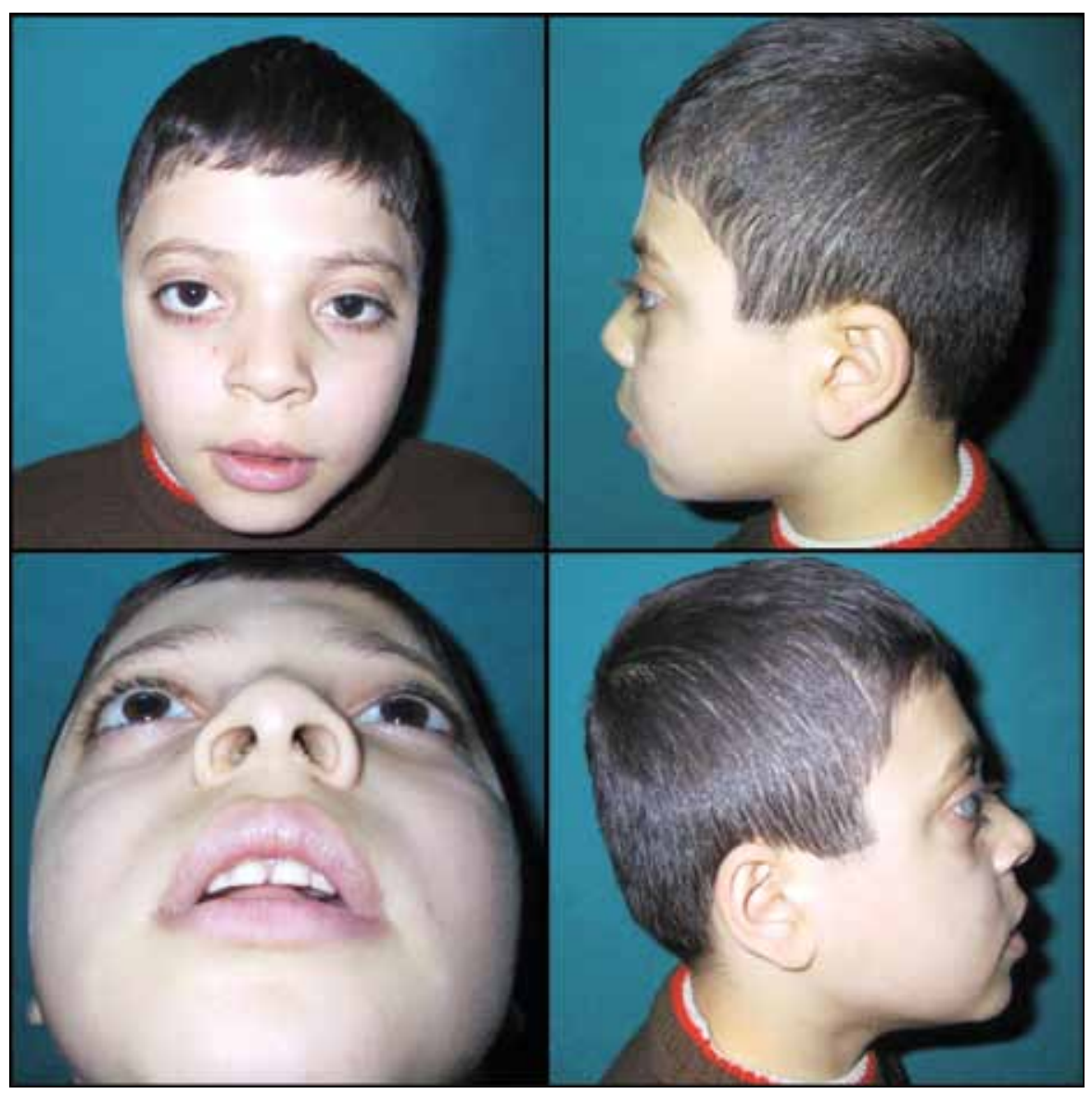

Figure 1: Views of the 8-year-old male patient with brachycephalic deformity due to synostosis of bicoronal sutures. Besides cranial vault dysmorphism, bilateral exorbitism is observed due to shallowness of the orbits. 

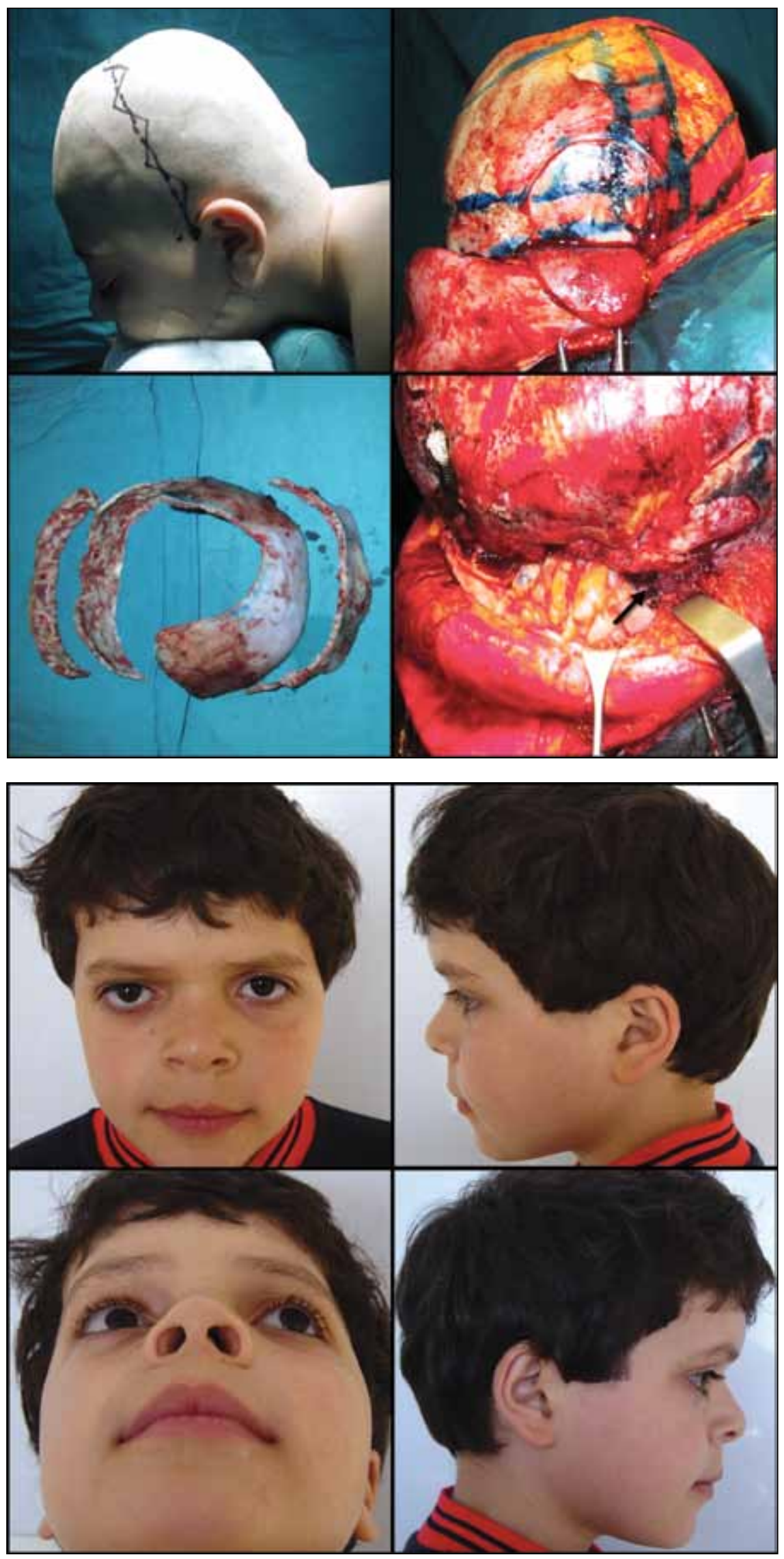

Figure 2: (Above, Left) Patient on the operating table, modified prone position showing the brachycephalic deformity. (Above, Right) Intraoperative view showing osteotomy designs for correction of the cranial vault deformity simultaneously with orbital decompression. (Below, Left) Craniotomy skull bones removed in four pieces. The frontal bone was advanced with the lateral orbital rim left intact. (Below, Right) Orbital decompression via lateral orbital wall decompression (arrow) and orbital periosteal scoring showing protrusion of orbital fat content into the orbital volume.
Figure 3: Views of the patient in the postoperative second year period. Note the regression of globe protrusion and correction of the cranial deformity. 


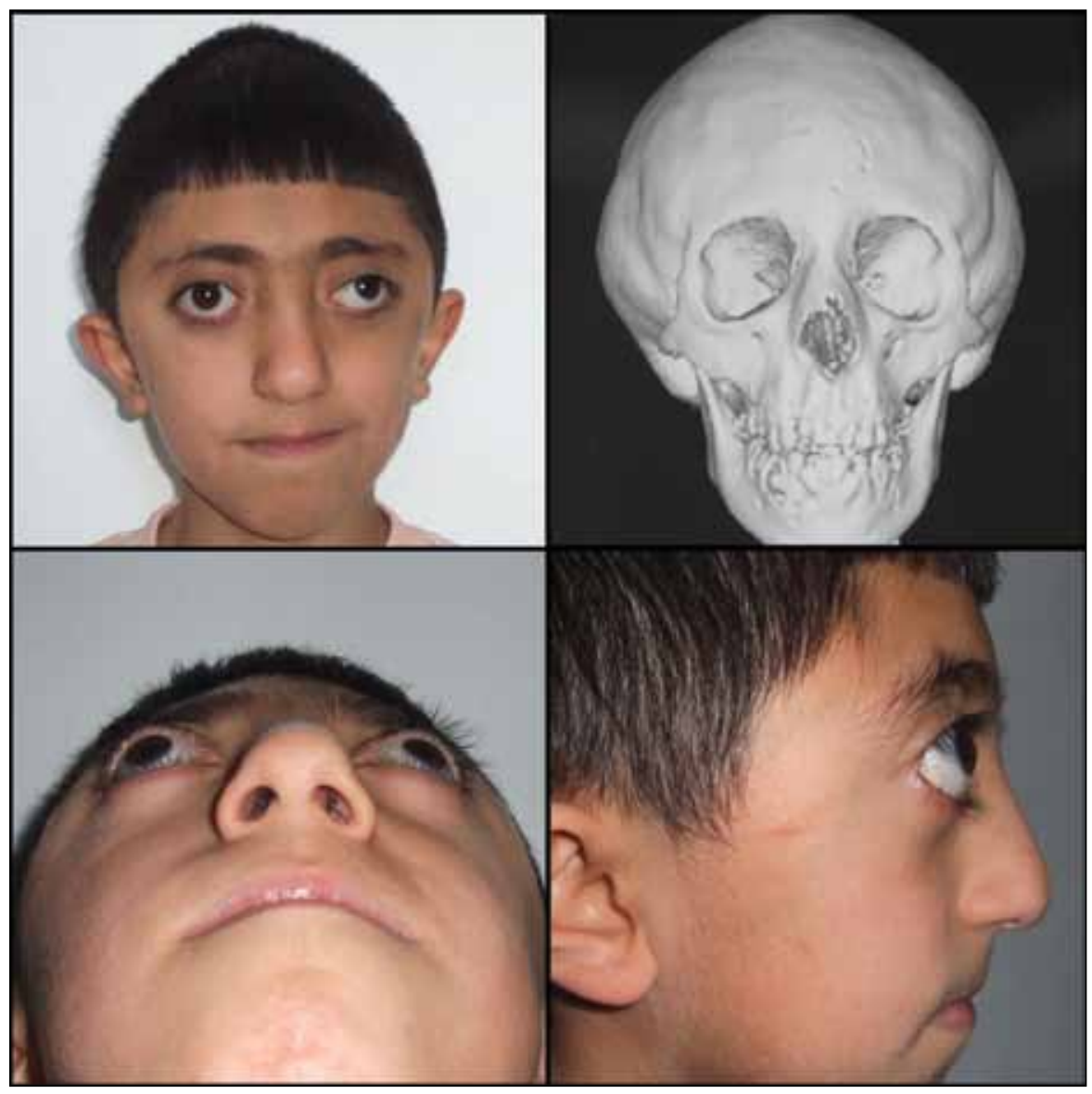

Figure 4: Views of the 10-year-old patient with a cranial vault deformity due to multiple suture synostoses and bilateral exorbitism. (Above, Right) AP skull radiograph showing early closure of multiple cranial sutures.

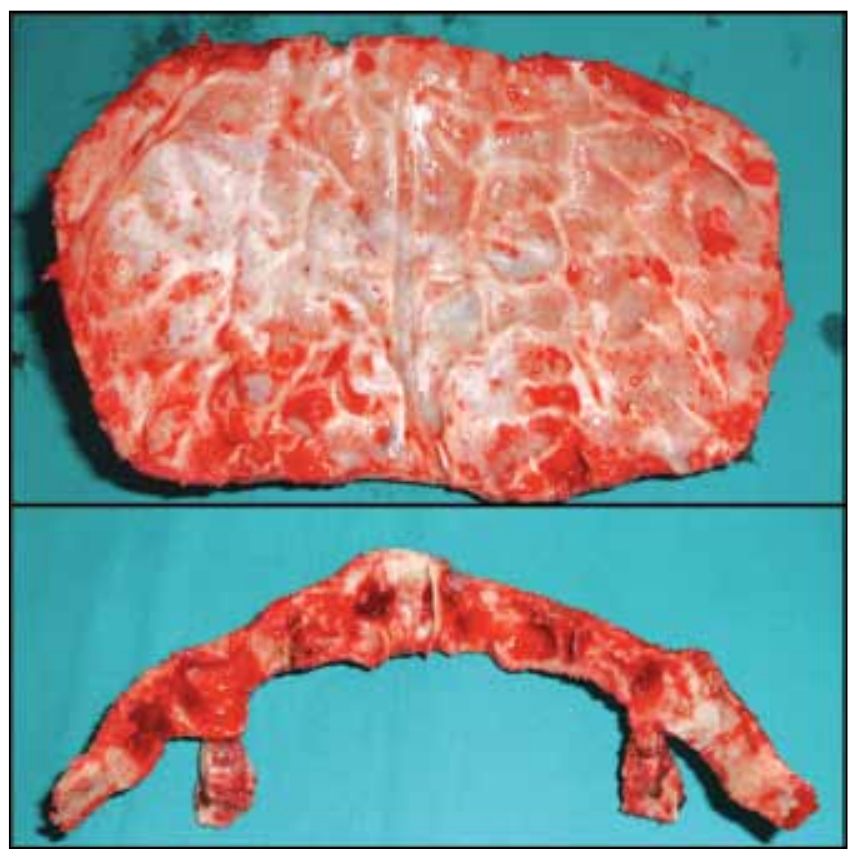

Figure 5: (Above) Frontal bone removed prior to advancement. Note the copper-beaten appearance due to elevated intracranial pressure. (Below) Frontal bar and lateral orbital rim removed as one piece. the upper eyelid posterior to the globe equator provokes an axial globe subluxation (10), resulting in ocular or eyelid dislocation.

Surgical correction of exorbitism allows the surgeon to obtain a stable and normal anteroposterior globe position. When a frontofacial advancement is performed, the orbital walls are transected and moved forward, increasing the volume of the bony orbit (5). This maneuver however will not be fully effective without periosteal scoring which facilitates herniation of the periocular fat into the expanded orbit.

Periosteal scoring has the potential side effects of restricted eye movements or orbital asymmetry. These can however be minimized by just performing the scoring to the superior portion of the globe periosteum minimizing trauma to the periocular muscles.

Fronto-orbital advancement and orbital wall decompression techniques resulting in an increase in intraorbital volume are often used in operations for exophthalmus due to increased intraorbital content. Other techniques used besides advancement and decompression procedures are removal of the excess orbital content including soft tissue or bony resections.

It should be noted that globe protrusion can also occur in diseases other than craniosynostosis for which the treatment 

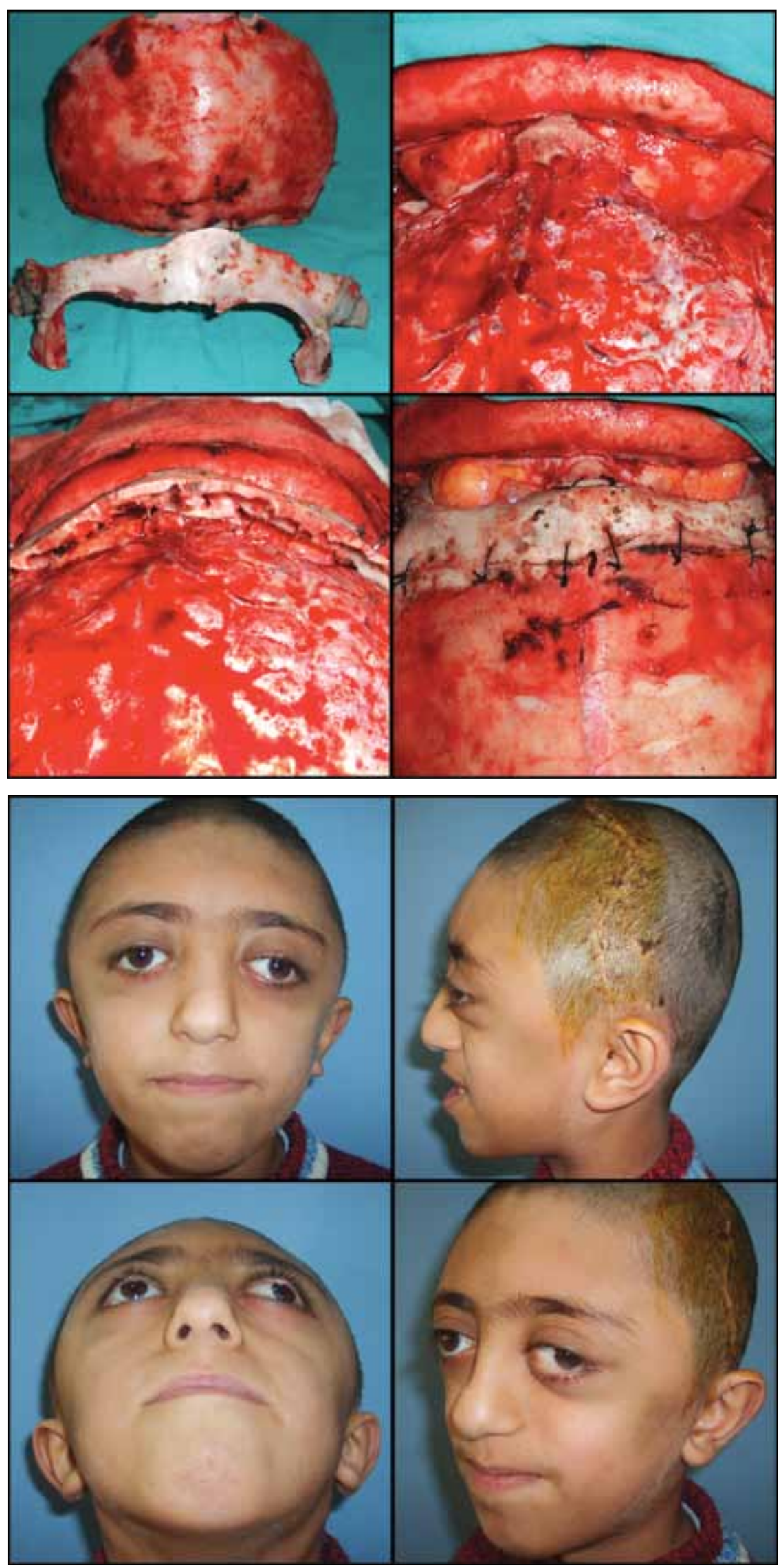

Figure 6: Intraoperative view of the patient. (Above, Left) The frontal bone and the frontal bar/lateral orbital rim bones on the operating table prior to advancement. (Above, Right) Partial bilateral orbital decompression prior to orbital periosteal scoring. (Below, Left) Frontal bone after fixation showing frontal advancement. (Below-Right) Orbital periosteal scoring resulting in decompression of the orbital content showing protrusion of orbital fat content into the orbital volumes.
Figure 7: Views of the patient in the early postoperative period. Note regression of globe protrusion and correction of the cranial deformity. 
strategies differ. Therefore an investigation for Graves' ophthalmopathy or myopia may be required (7). Although not so mandatory in the typical craniosynostosis patient for which the operation is planned early in life, specific attention and hence appropriate investigation should be made in cases of late referral as in the cases presented in this paper.

The prevalence of papilledema and increased intracranial pressure is high especially in syndromic craniosynostosis for which bilateral papilledema is seen commonly. Papilledema may be asymptomatic or present with headache in the early stages however it may progress to enlargement of the blind spot, blurring of vision, visual obscurations and ultimately total loss of vision may occur. Exorbitism is a factor shown to be associated with papilledema (1) as seen in our patients hence surgical treatment of exorbitism will ultimately cause regression of papilledema and alleviation of visual symptoms if present.

Fronto-orbital advancement has been shown to restore normal growth of the orbital volume however surgery should be delayed until the end of the second half of the first year of life, thus maximizing the effects of accelerated normal orbital growth and reducing the risks of relapse (3). This however is not a matter of value in our cases which are cases of late presentation.

Regarding the etiologies of exorbitism, the different mechanisms of globe protrusion have to be taken into account before an orbital surgical procedure is planned. Besides clinical evaluation, a preoperative morphological analysis of the orbital shape permits a precise analysis of the relative position of the ocular globe and orbital structures for this purpose.

In addition to the fronto-orbital bar and if needed orbital wall decompressions used in craniosynostosis surgery, we would like to emphasize the orbital periosteum scoring that will successfully result in orbital fat decompression which is definitely required to fill-in the expanded orbital volume. Expanding the orbital volume will not be sufficient for reduction of the exorbitism without periosteum scoring, which will cause herniation of the periocular fat into the expanded orbit. This simple but highly efficient technique is a competent way of orbital volume decompression in concordance with increasing the orbital bony volume.

The late admission of the patients at ages of 8 and 10 made the planning of the operation beyond typical craniosynostosis surgeries requiring a laborious design and difficult intraoperative shaping of the skull bones.
We hereby present our successfully treated cases of exorbitism due to shallowness of the orbits using frontal bar advancement, orbital wall decompression and periosteal scoring in junction with repair of the craniosynostosis.

\section{CONCLUSION}

In conclusion, exorbitism associated with craniosynostosis can be successfully repaired using the advancement and decompression methods performed simultaneously with cranial reshaping surgery. As a difficult procedure in ages older than infancy, periosteal scoring is highly effective for orbital decompression and in reducing globe proptosis.

\section{REFERENCES}

1. Bannink N, Joosten KF, van Veelen ML, Bartels MC, Tasker RC, van Adrichem LN, van der Meulen JJ, Vaandrager JM, de Jong TH, Mathijssen IM: Papilledema in patients with Apert, Crouzon, and Pfeiffer syndrome: prevalence, efficacy of treatment, and risk factors. J Craniofac Surg 19:121-127, 2008

2. Baujat B, Krastinova D, Bach CA, Coquille F, Chabolle F: Orbital morphology in exophthalmos and exorbitism. Plast Reconstr Surg 117:542-550, 2006

3. Bentley RP, Sgouros S, Natarajan K, Dover MS, Hockley AD: Changes in orbital volume during childhood in cases of craniosynostosis. J Neurosurg 96:747-754, 2002

4. Britto JA, Evans RD, Hayward RD, Jones BM: Maxillary distraction osteogenesis in Pfeiffer's syndrome: Urgent ocular protection by gradual midfacial skeletal advancement. Br J Plast Surg 51:343-349, 1998

5. Cruz AA, Akaishi PM, Arnaud E, Marchac D, Renier D: Exorbitism correction of faciocraniosynostoses by monobloc frontofacial advancement with distraction osteogenesis. J Craniofac Surg 18:355-360, 2007

6. Havlik RJ, Bartlett SP:The treatment of "malignant" exorbitism with an extended supraorbital advancement. Plast Reconstr Surg. 95:1094-1097, 1995

7. Krastinova-Lolov D, Bach CA, Hartl DM, Coquille F, Jasinski M, Cecchi P, Baujat B: Surgical strategy in the treatment of globe protrusion depending on its mechanism (Graves' disease, nonsyndromic exorbitism, or high myopia). Plast Reconstr Surg. 117:553-564, 2006

8. Mulliken JB, Godwin SL, Pracharktam N, Altobelli DE: The concept of the sagittal orbital-globe relationship in craniofacial surgery. Plast Reconstr Surg 97:700-706, 1996

9. Newman SA: Ophthalmic features of craniosynostosis. Neurosurg Clin N Am 2:587-610, 1991

10. Rubin PA, Watkins LM, Rumelt S, Sutula FC, Dallow RL: Orbital computed tomographic characteristics of globe subluxation in thyroid orbitopathy. Ophthalmology 105:2061-2064, 1998 